FEB 271396

OSTI

\title{
Contamination Source Review for Building E5485, Edgewood Area, Aberdeen Proving Ground, Maryland
}

Energy Systems Division

Argonne National Laboratory

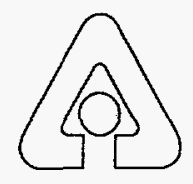

Operated by The University of Chicago,

nder Contract W-31-109-Eng-38, for the

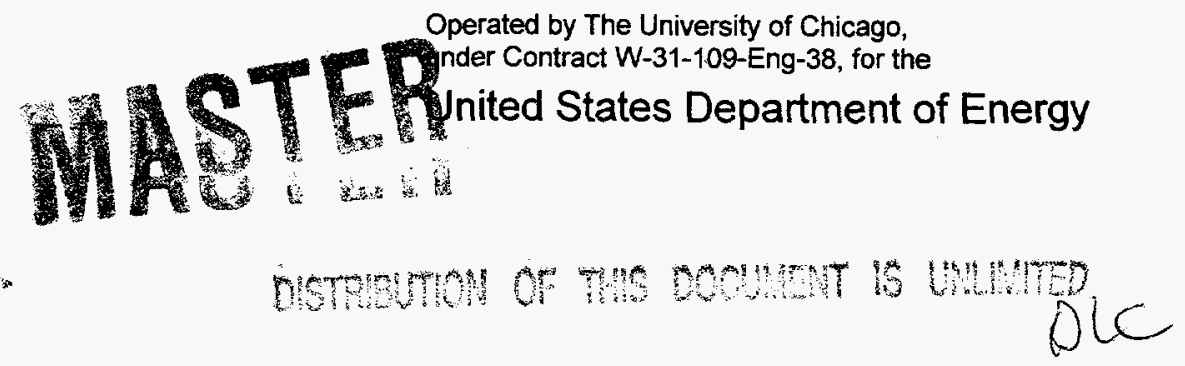




\section{Argonne National Laboratory}

Argonne National Laboratory, with facilities in the states of Illinois and Idaho, is owned by the United States Government, and operated by the University of Chicago under the provisions of a contract with the Department of Energy.

This technical memo is a product of Argonne's Energy Systems (ES) Division. For information on the division's scientific and engineering activities, contact:

Director, Energy Systems Division

Argonne National Laboratory

Argonne, Illinois 60439-4815

Telephone (708) 252-3724

Presented in this technical memo are preliminary results of ongoing work or work that is more limited in scope and depth than that described in formal reports issued by the ES Division.

Publishing support services were provided by Argonne's Information and Publishing Division (for more information, see IPD's home page: http:/hwww.ipd.anl.gov/).

\section{Disclaimer}

This report was prepared as an account of work sponsored by an agency of the United States Government. Neither the United States Government nor any agency thereof, nor any of their employees, makes any warranty, express or implied, or assumes any legal liability or responsibility for the accuracy, completeness, or usefulness of any information, apparatus, product, or process disclosed, or represents that its use would not infringe privately owned rights. Reference herein to any specific commercial product, process, or service by trade name, trademark, manufacturer, or otherwise, does not necessarily constitute or imply its endorsement, recommendation, or favoring by the United States Government or any agency thereof. The views and opinions of authors expressed herein do not necessarily state or reflect those of the United States Government or any agency thereof. 


\section{DISCLAMERR}

Portions of this document may be illegible in electronic image products. Images are produced from the best available original document. 


\section{Contamination Source Review for Building E5485, Edgewood Area, Aberdeen Proving Ground, Maryland}

K.A. Billmark, D.C. Hayes, A.K Draugelis, J. Rueda, and R.E. Zimmerman

Center for Environmental Restoration Systems, Energy Systems Division,

Argonne National Laboratory, 9700 South Cass Avenue, Argonne, Illinois 60439

\section{Published as}

Contamination Source Review

Edgewood Area, Aberdeen Proving

Ground, Maryland -

Building E5485

September 1995

Work sponsored by United States Department of Defense, United States Army, Aberdeen Proving Ground, Maryland 
बत्

This report is printed on recycled paper. 


\section{Contents}

Summary

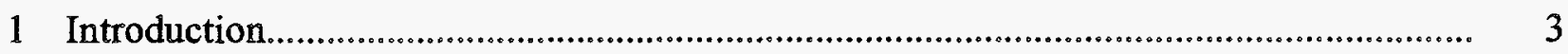

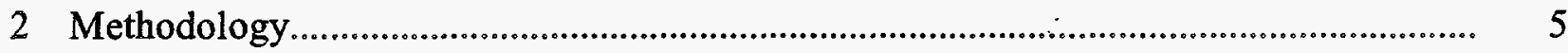

3 Historical Record Search ...................................................................................................... 6

4 Building Description .......................................................................................................

4.1 Site Description....................................................................................................

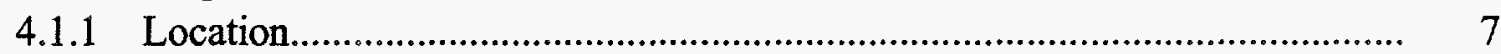

4.1.2 Proximity to Other Buildings ...................................................................... 7

4.1.3 Building Structure............................................................................................. 7

4.1.4 Exterior Dimensions.................................................................................. 7

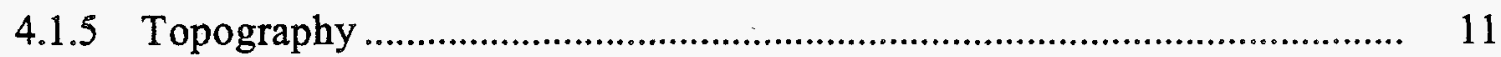

4.1.6 Vegetation in the Immediate Vicinity ...........................................................

4.1.7 External Aboveground Structures or Equipment......................................... 11

4.1.8 Connections with Adjacent Buildings ...................................................... 11

4.1.9 Underground Structures ..................................................................... 11

4.1.10 Surface Drainage System ...................................................................... 11

4.1.11 Utility Access Points.............................................................................. 11

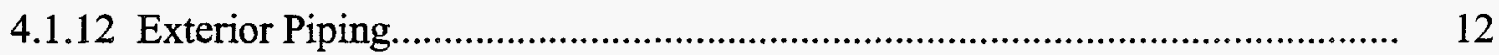

4.1.13 Nearby Roads and Sidewalks ................................................................ 12

4.2 North Exterior Elevation ................................................................................... 12

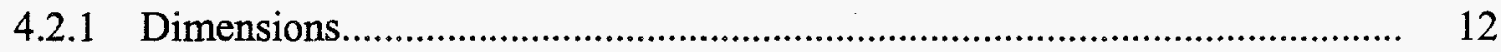

4.2.2 Construction Materials ......................................................................... 12

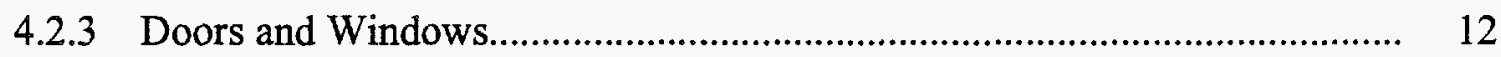

4.2.4 Piping ................................................................................................ 12

4.2.5 Utility Connections......................................................................... 12

4.2.6 External Equipment or Structures ............................................................ 13

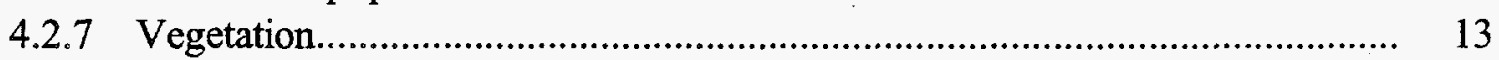

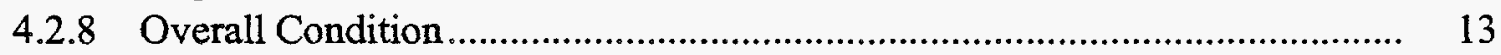

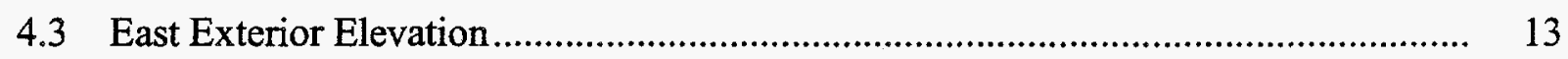

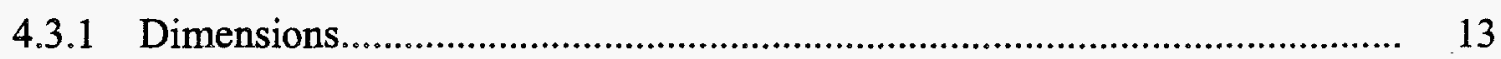

4.3.2 Construction Materials ............................................................................... 13

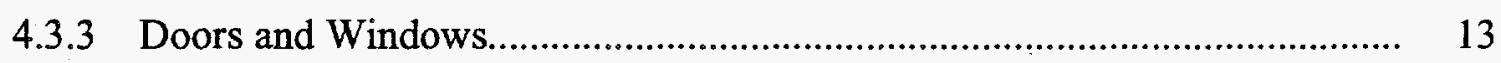

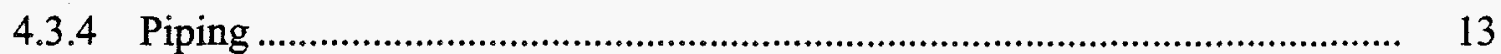

4.3.5 Utility Connections........................................................................ 14

4.3.6 External Equipment or Structures .......................................................... 14 


\section{Contents (Cont.)}

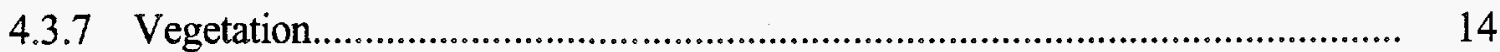

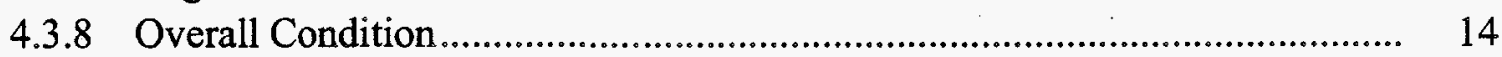

4.4 South Exterior Elevation......................................................................................... 14

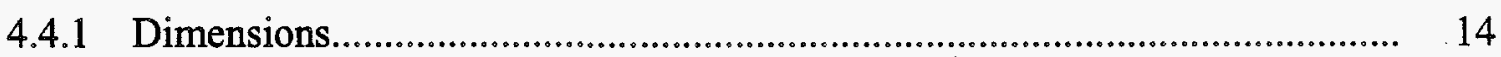

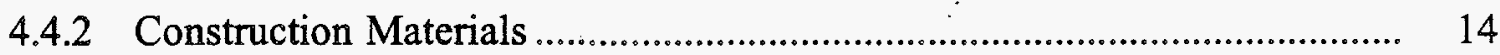

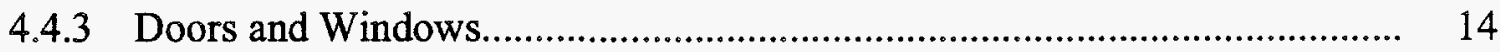

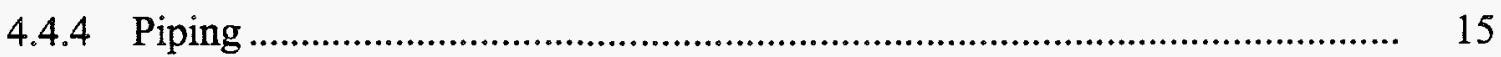

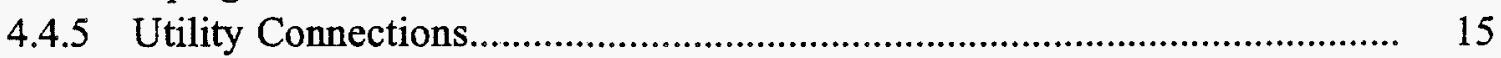

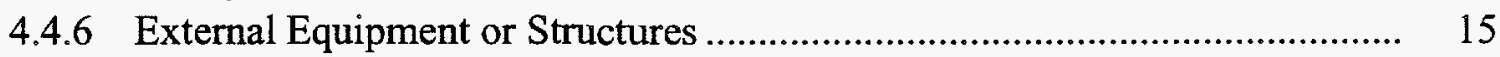

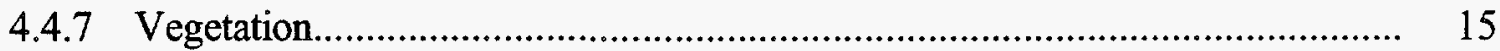

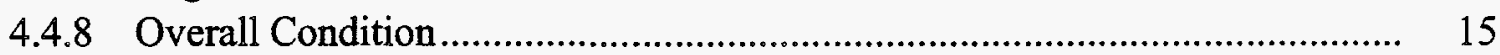

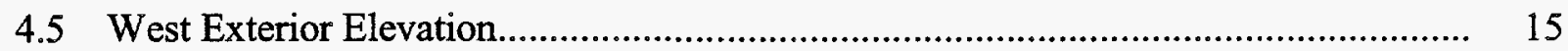

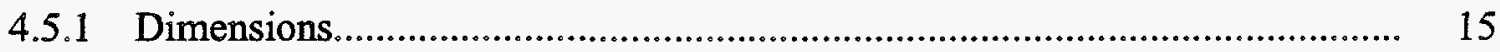

4.5.2 Construction Materials .......................................................................... 15

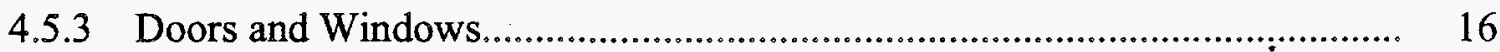

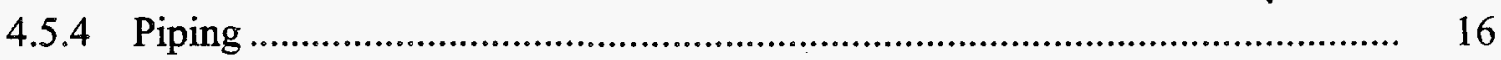

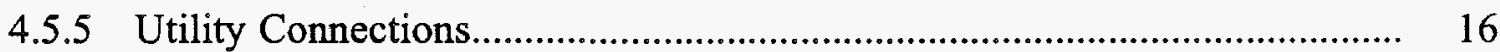

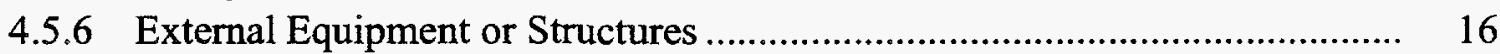

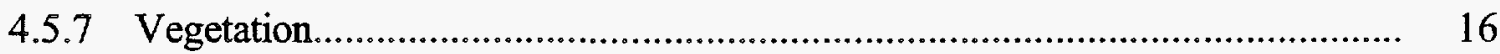

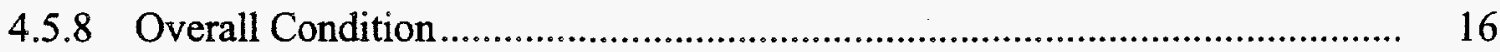

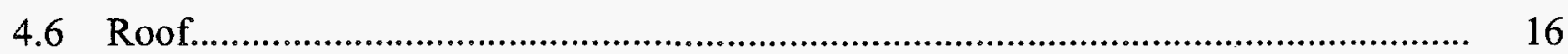

4.6.1 Type and Dimensions .................................................................. 16

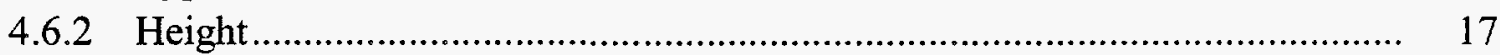

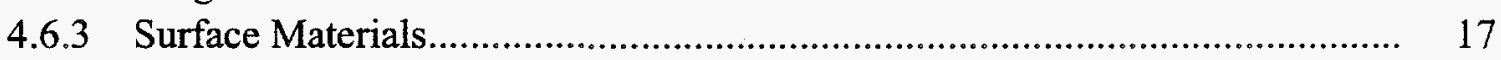

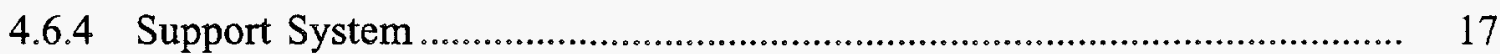

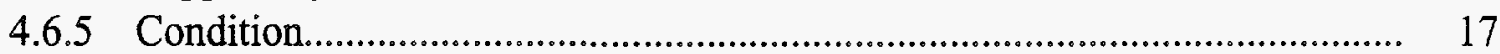

4.6.6 Equipment Located on Roof .................................................................... 17

4.6.7 Chimneys, Roof Vents, or Vent Stacks..................................................... 17

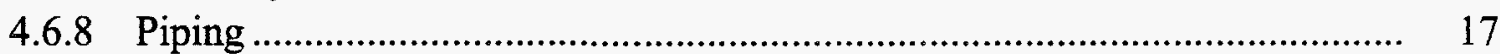

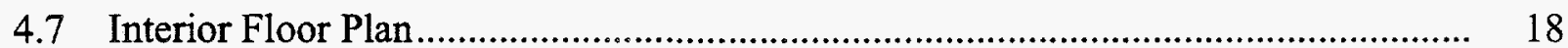

4.7.1 Room Numbers and Dimensions............................................................. 18

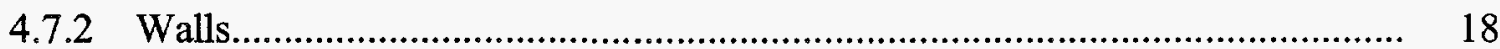

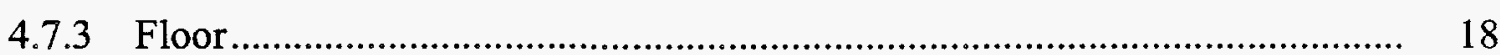

4.7.4 Floor Penetrations ..................................................................................... 18

4.7.5 Interior Partitions ....................................................................................... 18

4.7.6 Equipment or Supplies........................................................................... 18

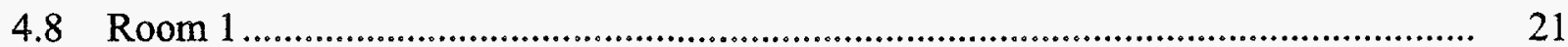

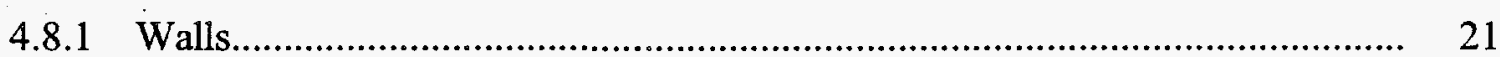

4.8.2 Finish Materials .................................................................................... 21

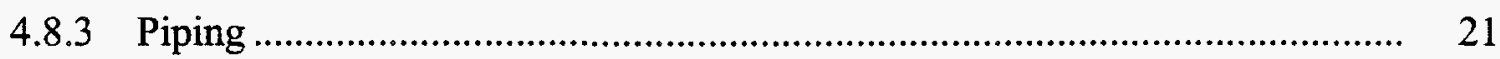




\section{Contents (Cont.)}

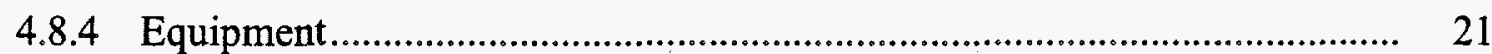

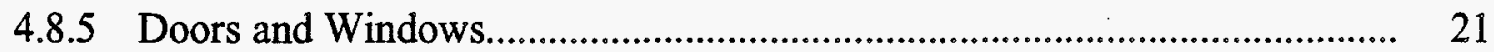

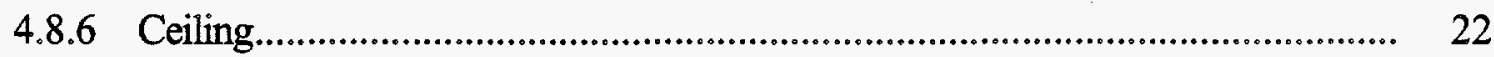

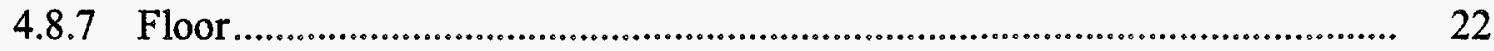

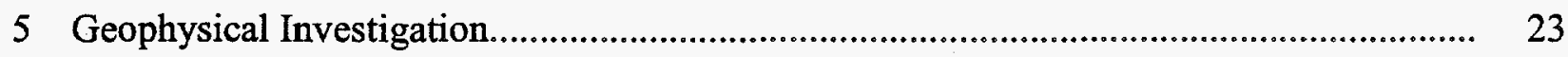

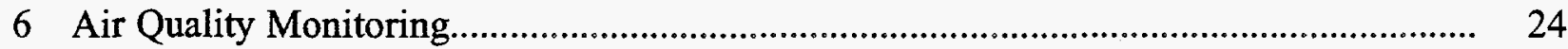

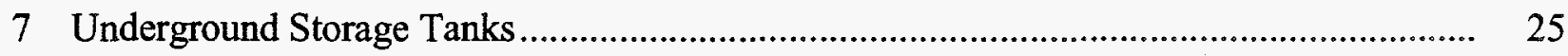

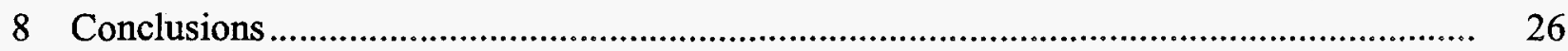

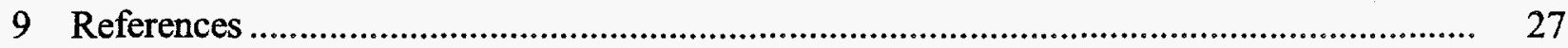

Appendix: Air Quality Monitoring Report ……................................................................... 29

Figures

1 Map of Aberdeen Proving Ground Location ....................................................................... 4

2 Map of Building E5485 Location................................................................................. 8

3 Building E5485 Floor Plan ..................................................................................

4 Photographs of Building E5485 Exterior........................................................................ 10

5 Photographs of Building E5485 Interior — Walls ........................................................... 19

6 Photographs of Building E5485 Interior — Ceiling and Floor ......................................... 20 


\title{
Contamination Source Review for Building E5485, Edgewood Area, Aberdeen Proving Ground, Maryland
}

\author{
by \\ K.A. Billmark, D.C. Hayes, \\ A.K. Draugelis, J. Rueda, and R.E. Zimmerman
}

\section{Summary}

This report was prepared by Argonne National Laboratory (ANL) to document the results of a contamination source review of Building E5485 at the Aberdeen Proving Ground (APG) in Maryland. This report may be used to assist the U.S. Army in planning for the future use or disposition of this building. The review included a historical records search, physical inspection, photographic documentation, geophysical investigation, and collection of air samples.

Building E5485 (APG designation) is located in the drainage basin of the west branch of Canal Creek in the Edgewood Area of APG. The building was constructed in 1922 and used as a fan house for agent operations in Building E5487 from 1925 to 1966. Building E5485 was then used as a laboratory to support manufacturing and storage of flammable agents from 1966 until 1967 , when it was placed on the inactive list.

The physical inspection and photographic documentation of Building E5485 were completed in November 1994. The single-story, square structure contains one room. The $10-\mathrm{ft}$ by 12 -ft building is of wood frame construction. Exterior walls are wood covered with corrugated sheet metal. The roof, which slopes from east to west, is made of corrugated sheet metal. The building is on a concrete slab. The interior walls and ceiling are constructed of a wooden frame covered by corrugated sheet metal. A single light bulb fixture hangs from the center of the ceiling; electrical wire extends the length of the room. There was no evidence of plumbing or heating equipment or floor drains inside the building.

In December 1994, ANL staff conducted geophysical surveys in the immediate vicinity of Building E5485 by using several nonintrusive methods. Survey results suggest the presence of some underground objects near Building E5485, but they do not provide conclusive evidence of the source of geophysical anomalies observed during the survey.

Air quality samples were collected upwind, downwind, and inside Building E5485 in November 1994. Analytical results showed no distinguishable difference in hydrocarbon and chlorinated solvent levels between the two background samples and the sample collected inside Building E5485. These results indicate that Building E5485 is not a source of volatile organic compound contamination. 
No information was available regarding underground storage tanks associated with Building E5485.

On the basis of information collected and reviewed for Building E5485, it is the authors' judgment that no significant air contamination is associated with this building. The geophysical surveys indicate some anomalies in the vicinity of Building E5485 that warrant further investigation and evaluation. 


\section{Introduction}

The U.S. Army Aberdeen Proving Ground (APG) commissioned Argonne National Laboratory (ANL) to conduct a contamination source review to identify and define areas of toxic or hazardous contaminants and to assess the physical condition and accessibility of APG buildings (Brubaker et al. 1994). The information obtained from this review may be used to assist the U.S. Army in planning for the future use or disposition. of the buildings. The source contamination review consisted of the following tasks: historical records search, physical inspection, photographic documentation, geophysical investigation, and collection of air samples. This report provides the results of the source contamination review for Building E5485.

Located on Chesapeake Bay in Harford and Baltimore counties, Maryland, APG occupies approximately 30,000 acres. The facility is divided into the Aberdeen and Edgewood areas (Figure 1). The primary mission at APG has been the testing and evaluation of U.S. Army warfare materials. Since its beginning in 1917, the Edgewood Area of APG has been the principal location for chemical warfare agent research, development, and testing in the United States. APG was also used for producing chemical warfare agents during both world wars and has been a center for the storage of chemical warfare material (Nemeth 1989).

Many of the APG facilities constructed between 1917 and the 1960s are no longer used because of obsolescence and their poor state of repair. Because many of these buildings were used for research, development, testing, and/or pilot-scale production of chemical warfare agents and other military substances (such as incendiary materials or munitions containing these materials), the potential exists for portions of the buildings to be contaminated with these substances, their degradation products, and other laboratory or industrial chemicals. These buildings and associated structures or appurtenances (e.g., underground or aboveground storage tanks, pipes, sumps) may contribute to environmental concerns at APG. 


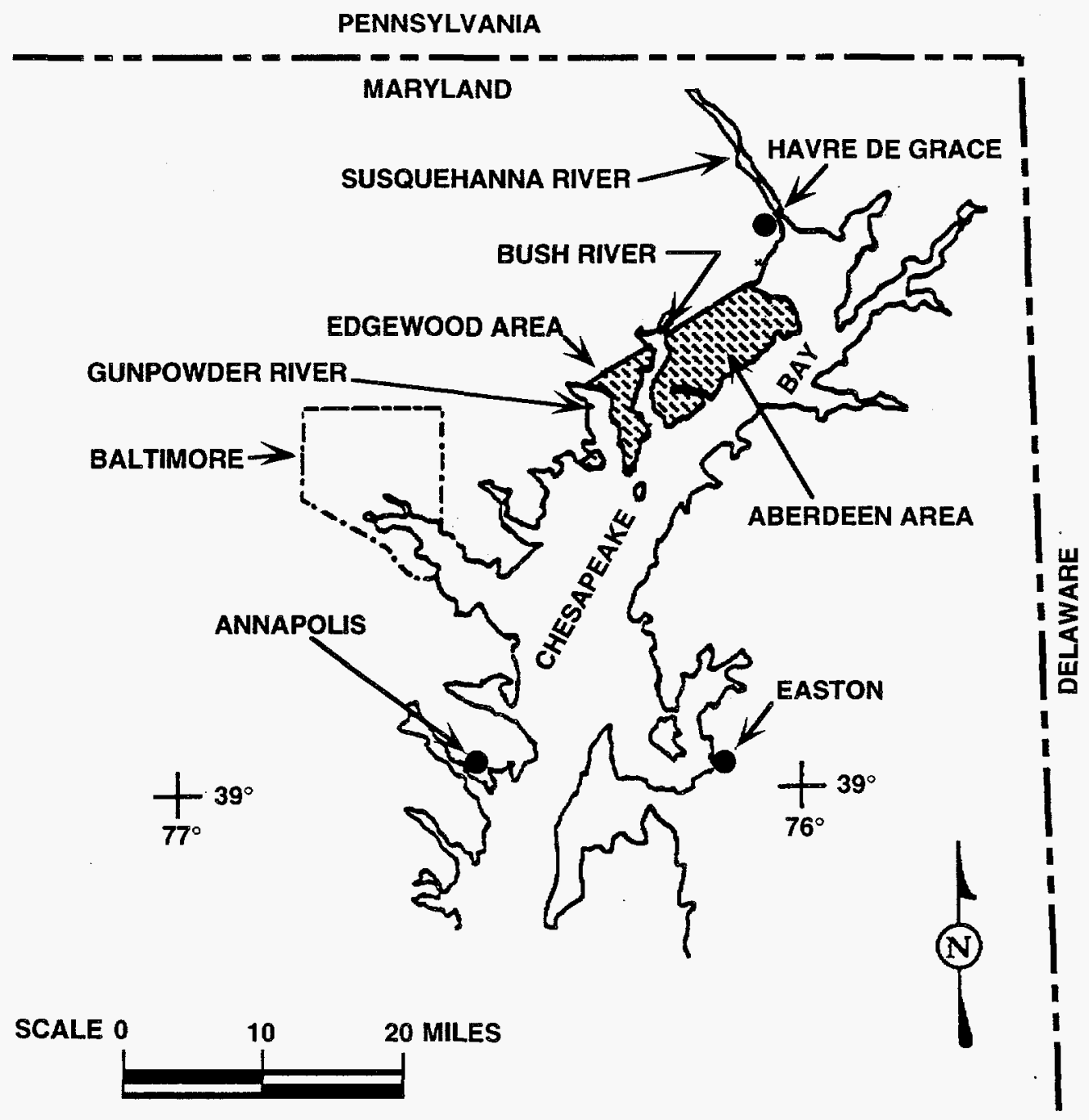

SII SHADED AREA INDICATES

ABERDEEN PROVING GROUND

FIGURE 1 Map of Aberdeen Proving Ground Location 


\section{Methodology}

Before the detailed building inspection, ANL personnel made a preliminary site visit to locate the building and obtain building records from APG, identify potential issues to be addressed in the health and safety plan, resolve any access restriction issues, and identify required support services.

Photographs were taken of the building's exterior and interior surfaces during the building inspection in November 1994. The photographs followed a set sequence whenever possible. The exterior was photographed starting on the north side and continuing clockwise around the building; walls were photographed starting in the north or northwest corner of each room and continuing clockwise until reaching the starting point. The ceiling and floor of each room were also photographed.

The area around Building E5485 was examined during December 1994 by using several nonintrusive geophysical survey methods, including total field magnetics, electrical conductivity (EM-31), time-domain electrical induction (EMF or EM-61), and ground-penetrating radar (GPR) techniques.

ANL staff collected air quality samples upwind, downwind, and inside of Building E5485 during November 1994. Organic compounds from 24-liter samples trapped in a sorbent polymer cartridge were thermally desorbed and analyzed by using a gas chromatograph equipped with a mass spectrometer. Compound identification was based on mass spectral interpretation and a computer search of the 140,000 compounds in the Wiley spectral library.

Detailed descriptions of the methodologies used for the air quality monitoring are provided in the appendix to this report. 


\section{Historical Record Search}

Building E5485 (APG designation) is located in the drainage basin of the west branch of Canal Creek in Edgewood Area of APG (Figure 1).

Building E5485 was built in 1922. It was used as a fan house for agent operations in support of Building E5487 from 1925 until 1966 (EAI Corporation 1989; Nemeth 1989). The outside equipment associated with the E5487 complex consisted of a $500-\mathrm{ft}^{3}$ gas holder (since removed), two concrete scrubbing towers (removed in 1966), compressed air drying apparatus (since removed), and vacuum pump line scrubbers (since removed) (EAI Corporation 1989). Concrete foundations assumed to be for equipment and tank supports were found east of Building E5495 (Nemeth 1989). Building E5485 was then used as laboratory to support manufacturing and flammable storage from 1966 until 1967, when it was placed on the inactive list (EAI Corporation 1989; Nemeth 1989).

Building E5485 has been categorized as having unknown contamination because of its association with known agent operations. The possible contaminants are petroleum, oil, and lubricants (EAI Corporation 1989). No documentation was found regarding potential contaminants in this building (EAI Corporation 1989). 


\section{Building Description}

This section provides a detailed physical description of Building E5485 and the surrounding site as they appeared during the ANL inspection in November 1994. This physical description includes an account of the condition of the exterior walls, roof, interior walls, ceiling, and floor of the building. There was no evidence of plumbing, heating, or electrical connections or floor drains inside the building during the ANL inspection.

\subsection{Site Description}

\subsubsection{Location}

Building E5485 is located in the drainage basin of the west branch of Canal Creek in the Edgewood Area of APG.

\subsubsection{Proximity to Other Buildings}

Building E5485 is approximately $40 \mathrm{ft}$ south of Building E5487 and approximately $100 \mathrm{ft}$ southeast of Building E5489 (Figure 2).

\subsubsection{Building Structure}

Building E5485 is a single-story, one-room building on a concrete slab with corrugated sheet metal siding and roof supported by a wooden structural framework. The walls on the east side of the building are taller than those on the west side. The corrugated metal roof slants from east to west. Figure 3 shows the Building E5485 floor plan, developed from measurements taken during the ANL inspection and historical documentation (EAI Corporation 1989). Figure 4 presents photographs of the building exterior.

\subsubsection{Exterior Dimensions}

The exterior dimensions of Building E5485 are $10 \mathrm{ft}$ by $12 \mathrm{ft}$ (Figure 3). 


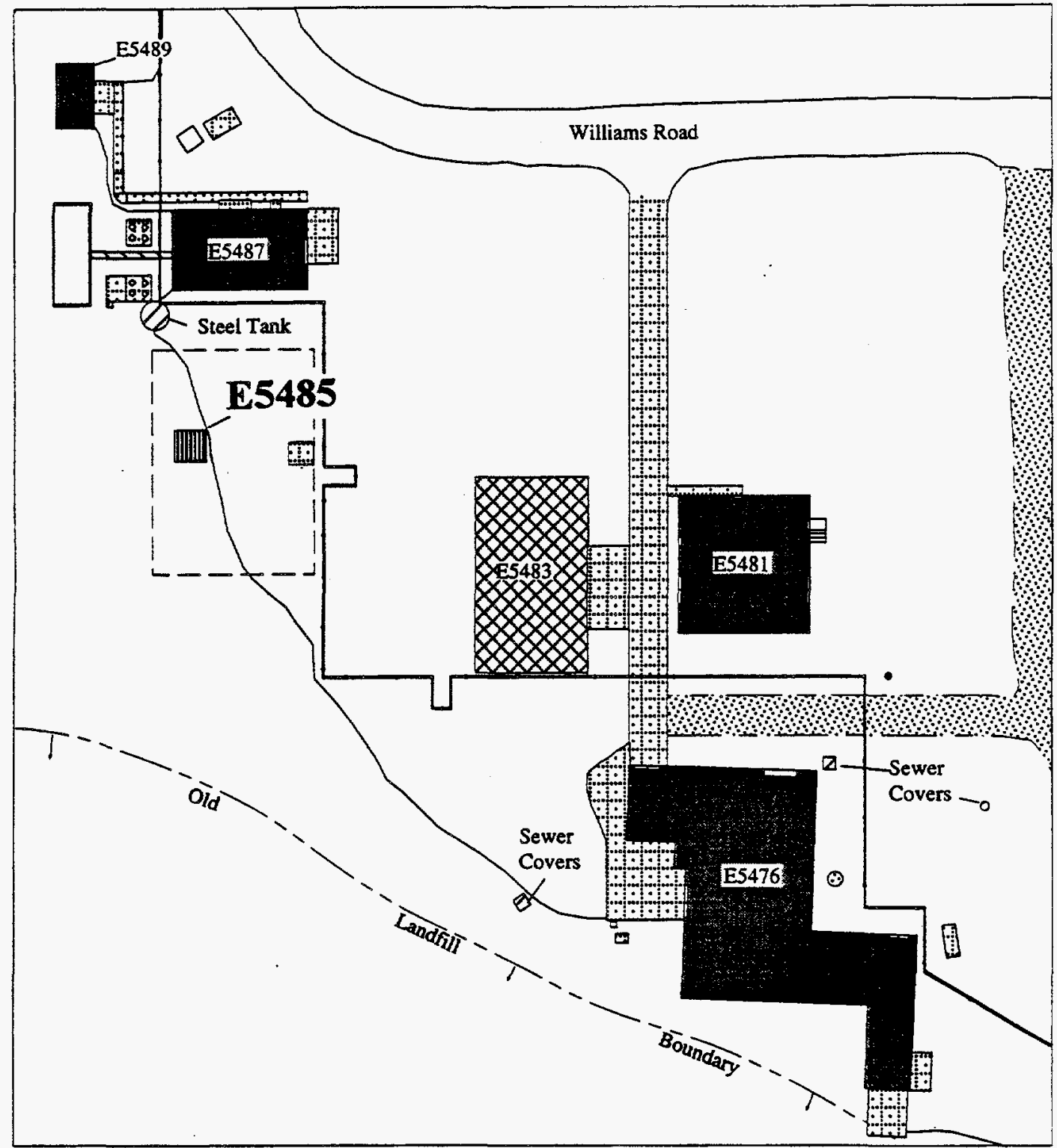

\section{EXPLANATION}

\section{때태 \\ FY 92 study building}

$\bigotimes$ Adjacent building not considered in study

Concrete

Area of tall grass and weeds

$\tau$ Old landfill

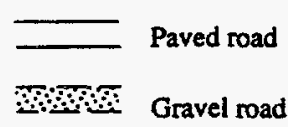

Overhead pipe (6" diameter) with steel support poles

T- ivesured grid boundary

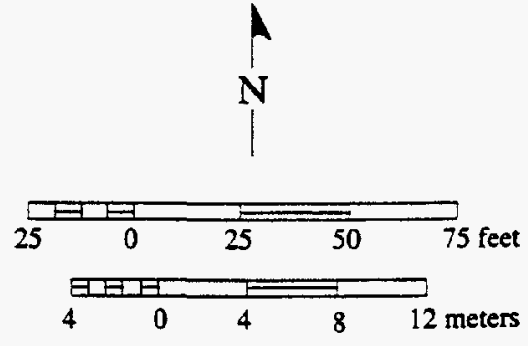

FIGURE 2 Map of Building E5485 Location 


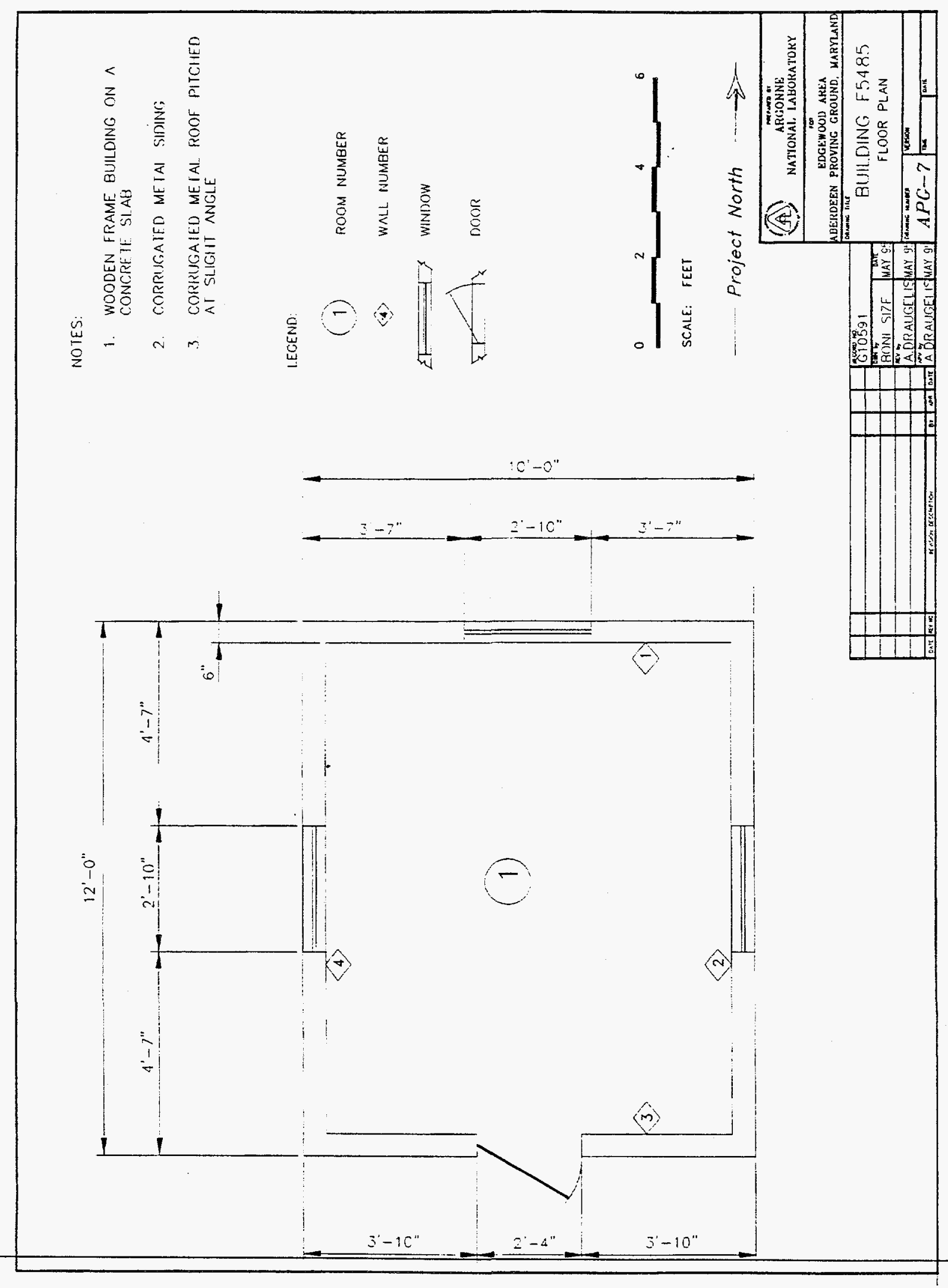

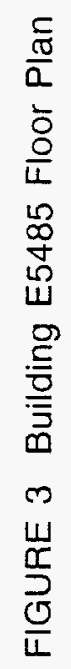





告 


\subsubsection{Topography}

The surface surrounding Building E5485 is soil covered with cut and uncut vegetation. The area slopes gently to the west and southwest, away from the building.

\subsubsection{Vegetation in the Immediate Vicinity}

The vegetation surrounding Building E5485 consists of cut grass and an uncut mixture of forbs, vines, and grasses. There are several trees growing along the south and west sides of the building (Figure 4).

\subsubsection{External Aboveground Structures or Equipment}

None.

\subsubsection{Connections with Adjacent Buildings}

None.

\subsubsection{Underground Structures}

None.

\subsubsection{Surface Drainage System}

None.

\subsubsection{Utility Access Points}

None. 
4.1.12 Exterior Piping

None.

4.1.13 Nearby Roads and Sidewalks

Building E5485 is located near the southwest corner of Williams Road.

\subsection{North Exterior Elevation}

\subsubsection{Dimensions}

The north exterior wall of Building E5485 measures $10 \mathrm{ft}$ long (Figure 3).

\subsubsection{Construction Materials}

The north exterior wall is constructed of a wood frame covered with corrugated sheet metal.

\subsubsection{Doors and Windows}

One window measuring $2 \mathrm{ft} 10 \mathrm{in}$. wide in the center of the north exterior wall is covered with plywood.

\subsubsection{Piping}

None.

\subsubsection{Utility Connections}

None. 


\subsubsection{External Equipment or Structures}

None.

\subsubsection{Vegetation}

The vegetation surrounding Building E5485 consists of cut grass and an uncut mixture of forbs, vines, and grasses.

\subsubsection{Overall Condition}

Because of a lack of building maintenance, the corrugated sheet metal walls are rusting; areas have been patched with corrugated sheet metal (Figure 4).

\subsection{East Exterior Elevation}

\subsubsection{Dimensions}

The east exterior wall of Building E5485 measures $12 \mathrm{ft}$ in length (Figure 3).

\subsubsection{Construction Materials}

The east wall is constructed of a wood frame covered with corrugated sheet metal.

\subsubsection{Doors and Windows} plywood.

A window in the center of the wall measuring $2 \mathrm{ft} 10 \mathrm{in}$. wide is covered up with 4.3.4 Piping

None. 


\subsubsection{Utility Connections}

None.

\subsubsection{External Equipment or Structures}

None.

\subsubsection{Vegetation}

The vegetation surrounding Building E5485 consists of cut grass and an uncut mixture of forbs, vines, and grasses.

\subsubsection{Overall Condition}

Because of a lack of building maintenance, the east exterior wall is rusting.

\subsection{South Exterior Elevation}

\subsubsection{Dimensions}

The south exterior wall of Building E5485 is $10 \mathrm{ft}$ long (Figure 3).

\subsubsection{Construction Materials}

The south exterior wall is constructed of a wood frame covered with corrugated sheet metal.

\subsubsection{Doors and Windows}

One wooden door measuring $2 \mathrm{ft} 4 \mathrm{in}$. wide is in the center of the south exterior wall. 


\subsubsection{Piping}

None.

\subsubsection{Utility Connections}

None.

\subsubsection{External Equipment or Structures}

None.

\subsubsection{Vegetation}

The vegetation surrounding Building E5485 consists of cut grass and an uncut mixture of forbs, vines, and grasses. There are several trees growing along the south side of the building (Figure 4).

\subsubsection{Overall Condition}

Because of a lack of building maintenance, the corrugated sheet metal walls are rusting.

\subsection{West Exterior Elevation}

\subsubsection{Dimensions}

The west exterior wall of Building E5485 is $12 \mathrm{ft}$ in length (Figure 3).

\subsubsection{Construction Materials}

The west exterior wall is constructed of a wood frame covered with corrugated sheet metal. 


\subsubsection{Doors and Windows}

One window measuring $2 \mathrm{ft} 10 \mathrm{in}$. wide is in the center of the west wall. Four of the six glass panes are broken out.

\subsubsection{Piping}

None.

\subsubsection{Utility Connections}

None.

\subsubsection{External Equipment or Structures}

None.

\subsubsection{Vegetation}

The vegetation surrounding Building E5485 consists of cut grass and an uncut mixture of forbs, vines, and grasses. There are several trees growing along the west side of the building (Figure 4).

\subsubsection{Overall Condition}

Because of a lack of building maintenance, the corrugated metal walls are rusting; some areas have been patched with corrugated sheet metal (Figure 4).

\subsection{Roof}

\subsubsection{Type and Dimensions}

The roof of Building E5485 slants from east to west at a slight angle (Figure 3). 


\subsubsection{Height}

The height of the eaves is approximately $10 \mathrm{ft}$ on the east side of Building E5485 and approximately $8 \mathrm{ft}$ on the west side.

\subsubsection{Surface Materials}

The roof of Building E5485 is made of corrugated sheet metal.

\subsubsection{Support System}

The roof is supported by a wooden frame.

\subsubsection{Condition}

Because of lack of a building maintenance, the roof is rusting. The roof has completely rusted away in one spot, revealing small holes along the frame.

\subsubsection{Equipment Located on Roof}

None.

\subsubsection{Chimneys, Roof Vents, or Vent Stacks}

None.

\subsubsection{Piping}

None. 


\subsection{Interior Floor Plan}

\subsubsection{Room Numbers and Dimensions}

Building E5485 consists of one room measuring $9 \mathrm{ft} 6 \mathrm{in}$. by $11 \mathrm{ft} 6 \mathrm{in}$. (Figures 3 and 5).

\subsubsection{Walls}

The interior walls of Building E5485 are constructed of corrugated sheet metal. Wooden shelves line two walls and half of a third wall (Figure 5).

\subsubsection{Floor}

The floor consists of a concrete slab (Figure 6).

\subsubsection{Floor Penetrations}

The concrete slab is in good condition, with no noticeable cracks.

\subsubsection{Interior Partitions}

None.

\subsubsection{Equipment or Supplies}

None. 

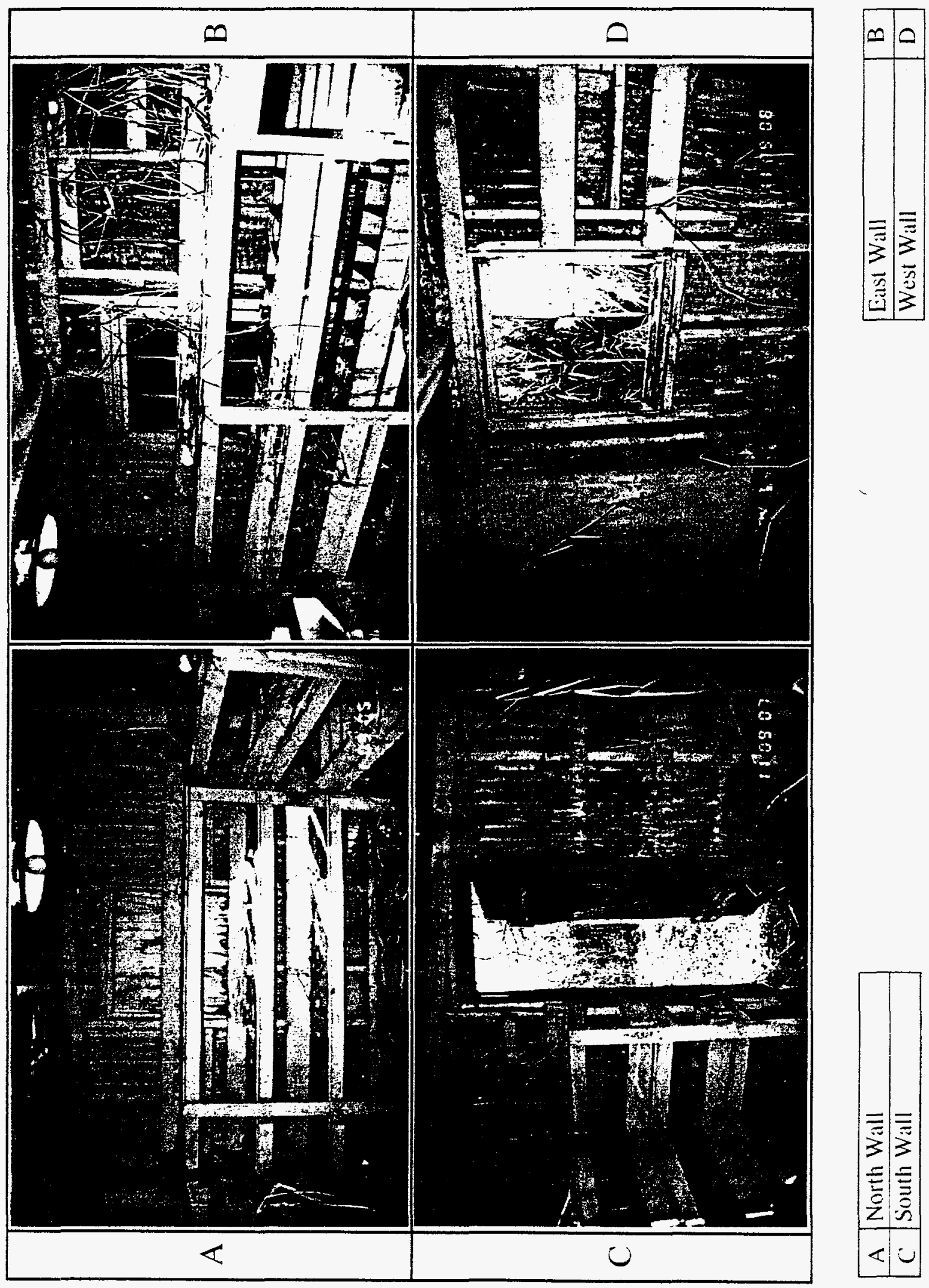

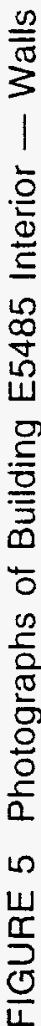



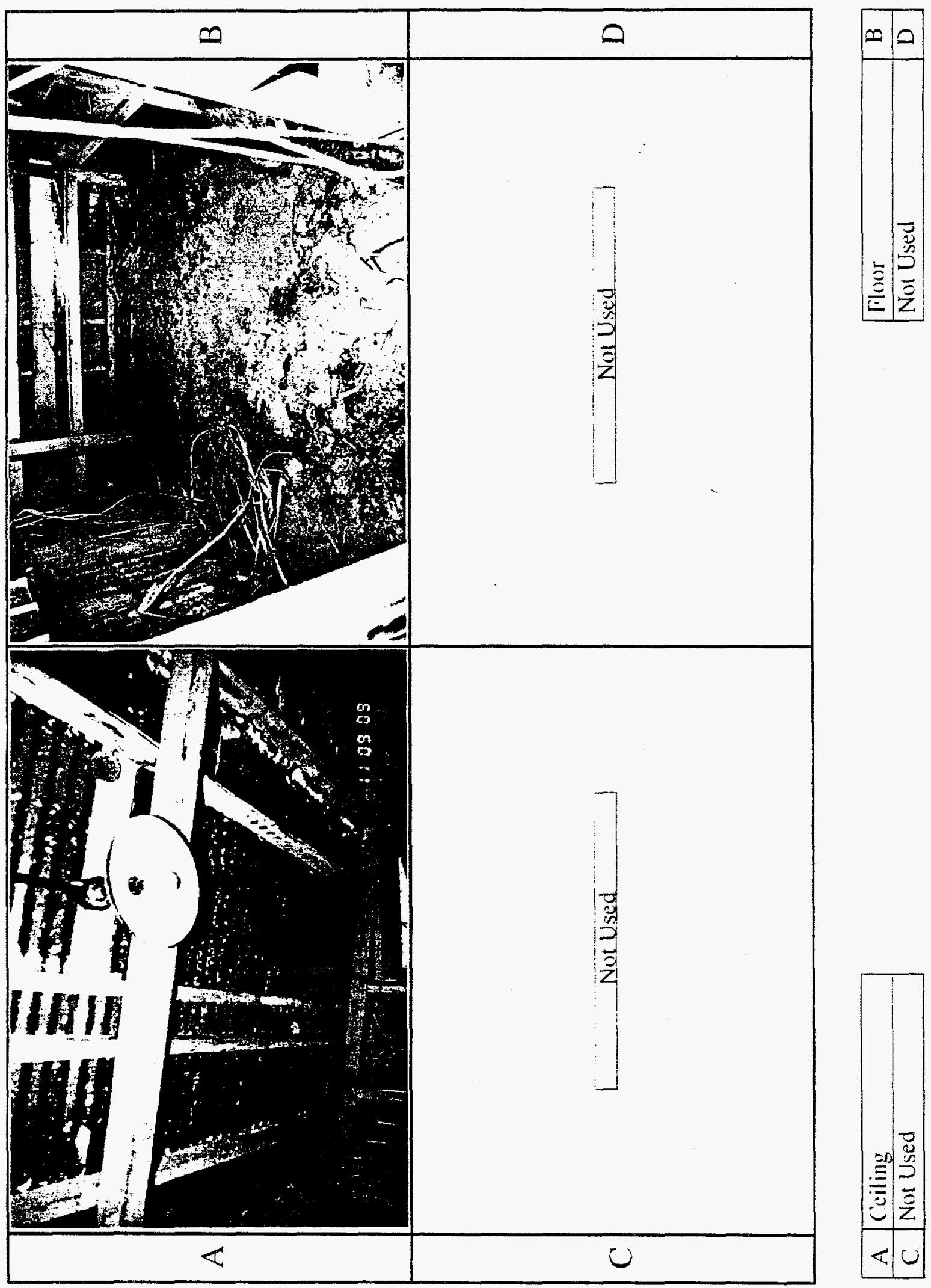

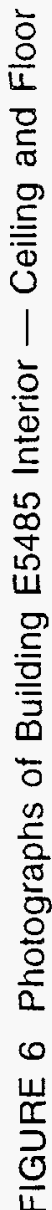

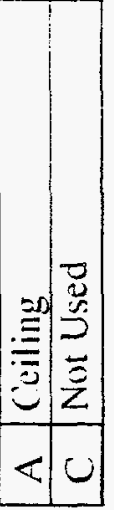




\subsection{Room 1}

\subsubsection{Walls}

The interior walls of Building E5485 are constructed of corrugated sheet metal. Along the entire length of the north wall, a three-tier shelf raised from off the floor extends up three-fourths of the wall. Along the entire length of the east wall is the three-tier shelf continuing from the north wall. On the bottom and middle tier is a frame with wooden dividers creating numerous separated compartments running the length of the shelf. The three-tier shelf continues to the south wall from the east wall with the separate compartments on the bottom and middle tier. West of the door is the corrugated sheet metal wall. A wooden board with nails on the west wall is for hanging implements and tools (Figure 5).

\subsubsection{Finish Materials}

The interior walls of Building E5485 are corrugated sheet metal (Figure 4).

\subsubsection{Piping}

None.

\subsubsection{Equipment}

None.

\subsubsection{Doors and Windows}

One wooden door measuring $2 \mathrm{ft} 4 \mathrm{in}$. wide is in the center of the south wall. Window openings measuring $2 \mathrm{ft} 10 \mathrm{in}$. wide, one each in the center of the north and east walls, are covered with plywood. One glass window measuring $2 \mathrm{ft} 10 \mathrm{in}$. wide is in the center of the west wall. Four of the six glass panes are broken out. 


\subsubsection{Ceiling}

The ceiling is corrugated sheet metal on a wooden frame. A single light bulb fixture hangs from the center of the ceiling; electrical wire extends the length of the room.

\subsubsection{Floor}

The floor is a concrete slab that is in good condition, with no noticeable cracks. 


\section{Geophysical Investigation}

ANL geophysical staff surveyed the area around Building E5485 by means of several nonintrusive geophysical survey methods (see Section 2). The geophysical investigation is detailed in McGinnis et al. 1994.

Results of the geophysical surveys revealed the following:

- A prominent northeast to southwest geophysical lineament crosses the complex; this feature, which may represent a sewer line system, is associated with a manhole located $16 \mathrm{ft}$ south of the southeast corner of Building E5485. The manhole is located in a grid of orthogonal geophysical lineaments that was observed in a combination of magnetic, EM-31, and EM-61 anomalies. One anomaly that was observed on all geophysical maps extends south from the east side of Building E5487 and connects with the prominent northeast to southwest lineament.

- High-amplitude magnetic and EM-61 anomalies along Williams Road suggest that, in addition to amphibolitic road fill, the road may be underlain by a ferromagnetic water main pipe.

- Unexplained magnetic point sources are randomly distributed throughout the "Ghost Town" complex, which encompasses Building E5485.

- Three or four lineaments in the southeast quadrant, indicating buried metallic objects, were observed with the EM-61. Unexplained lineaments were observed trending northwest-southeast in the southeast quadrant of the survey area. 


\section{Air Quality Monitoring}

ANL staff collected air quality samples upwind, downwind, and inside of Building E5485 during November 1994. Analytical results showed no distinguishable difference in the hydrocarbon and chlorinated solvent levels between the two background samples and the sample taken inside Building E5485. These results indicate that Building E5485 is not a source of volatile organic compound contamination. The air quality monitoring letter report (with data) is provided in the appendix. 


\section{Underground Storage Tanks}

No information related to underground storage tanks associated with Building E5485 was available. 


\section{Conclusions}

On the basis of information collected and reviewed by ANL for Building E5485, it is the authors' judgment that no significant air contamination is associated with this building. Results of the geophysical surveys indicate some anomalies in the vicinity of Building E5485 that warrant further investigation and evaluation. 


\section{References}

Brubaker, K.L., J.M. Dougherty, and L.D. McGinnis, 1994, Initial Building Investigation at Aberdeen Proving Ground, Maryland: Objectives and Methodology, ANL/ESD/TM-61, Argonne National Laboratory, Argonne, Ill.

EAI Corporation, 1989, Historical Records Search and Site Survey of the Edgewood Area Buildings - Final Report, prepared for U.S. Army Chemical Research, Development, and Engineering Center, Aberdeen Proving Ground, Maryland, under contract no. DAAIS-87-D0021.

McGinnis, L.D., M.D. Thompson, and S.F. Miller, 1994, Environmental Geophysics: Buildings E5485, E5487, and E5489 Decommissioning - the "Ghost Town" Complex, Aberdeen Proving Ground, Maryland, ANL/ESD/TM-78, Argonne National Laboratory, Argonne, Ill.

Nemeth, G., 1989, RCRA Facility Assessment Report, Edgewood Area, Aberdeen Proving Ground, Maryland, unnumbered report prepared for Aberdeen Proving Ground, Maryland. 
Appendix:

Air Quality Monitoring Report 
TO:

FROM:

Eric Zimmerman

John Schneider
Nancy Tomczyk 288

SUBJECT:

Building E5485 Air Monitoring for Volatile Organic Compounds Results

Air samples were collected and analyzed on-site at APG by ANL during the week of November 14, 1994. Samples were collected by drawing amblent air through a Tenax TA sorbent polymer sampling cartridge $(4 \mathrm{~mm}$ I.D. $\times 11.5 \mathrm{~cm})$ traps at the rate of $200 \mathrm{~mL}$ for 120 minutes, yielding a $24 \mathrm{~L}$ sample volume. The cartridges were analyzed by thermally desorbing the trapped organic compounds with a Dynatherm model 900 ACEM thermal desorption unit on to a Hewlett-Packard 5890 series II gas chromatograph (GC) equipped with a Hewlett-Packard 5972 mass spectrometer (MS).

The MS was used for detecting and identifying organic compounds desorbed from the Tenax traps. Spectra were obtained by scanning from 45 to 400 atomic mass units at a rate of two scans every second. Identifications were based on mass spectral interpretation and computer searching of the 140,000 compound Wiley spectral library. A standard mixture of volatile organics containing toluene at $200 \mathrm{ng} / \mathrm{uL}$ and other aromatic hydrocarbons, was run daily to assure that the instrument was operating properly. All quantitations are estimates, using the assumption that analyte response factors should be similar to toluene in the standard mixture of volatile organics.

The majority of the volatile organic compounds found during the ANL air monitoring are commonly found in any building (hydrocarbons and chlorinated solvents). The following compounds were the major components found in the air samples:

\begin{tabular}{|c|c|c|c|}
\hline Compound & E5485 & Upwind & ownwing \\
\hline $\begin{array}{l}\text { Benzene } \\
\text { Toluene } \\
\text { Hexanal } \\
\text { Tetrachloroethene } \\
\text { Ethyl Benzene } \\
\text { Xylenes } \\
\text { Alpha Pinene } \\
\text { Benzaldehyde } \\
\text { Phenol } \\
\text { Beta Pinene } \\
\text { Methyl Phenyl Ketone }\end{array}$ & $\begin{array}{l}0.07 \mathrm{ng} / L \\
0.12 \mathrm{ng} / L \\
0.01 \mathrm{ng} / \\
0.01 \mathrm{ng} \Omega \\
0.02 \mathrm{ng} \Omega \\
0.06 \mathrm{ng} \Omega \\
0.005 \mathrm{ng} / \\
0.26 \mathrm{ng} / \\
0.07 \mathrm{ng} / \\
0.01 \mathrm{ng} / \\
0.18 \mathrm{ng} \Omega\end{array}$ & $\begin{array}{l}0.08 \mathrm{ng} / \\
0.22 \mathrm{ng} / \mathrm{L} \\
0.004 \mathrm{ng} / \\
0.03 \mathrm{ng} / \\
0.04 \mathrm{ng} / \\
0.13 \mathrm{ng} / \\
0.05 \mathrm{ng} / \\
0.74 \mathrm{ng} / \\
0.13 \mathrm{ng} / \\
0.01 \mathrm{ng} / \\
0.50 \mathrm{ng} /\end{array}$ & $\begin{array}{l}0.09 \mathrm{ng} \Omega \\
0.11 \mathrm{ng} \Omega \\
0.01 \mathrm{ng} \Omega \\
0.01 \mathrm{ng} \Omega \\
0.02 \mathrm{ng} \Omega \\
0.07 \mathrm{ng} \Omega \\
0.04 \mathrm{ng} \Omega \\
0.55 \mathrm{ng} \Omega \\
0.14 \mathrm{ng} \Omega \\
\text { ND } \\
0.44 \mathrm{ng} \Omega\end{array}$ \\
\hline
\end{tabular}

Figure 1 is a total ion chromatogram (TIC) of the air sample taken in E5485. Figures 2 and 3 are TICs of the outside air samples. Table $I$ is the air sampling data sheet.

The analysis indicates that Building E5485 is not a source of volatile organic compound contamination.

JFSNAT:Ils

Attachments 
File

: A: $1 A 276 . D$

Operator

- lar

Acquired

Instrument :

: 19 Nov 94 10:28 pm using AcqMethod PILOT

Misc Info : start, $200 \mathrm{~mL} / \mathrm{min}$ end, facing ceiling

Vial Number: 1

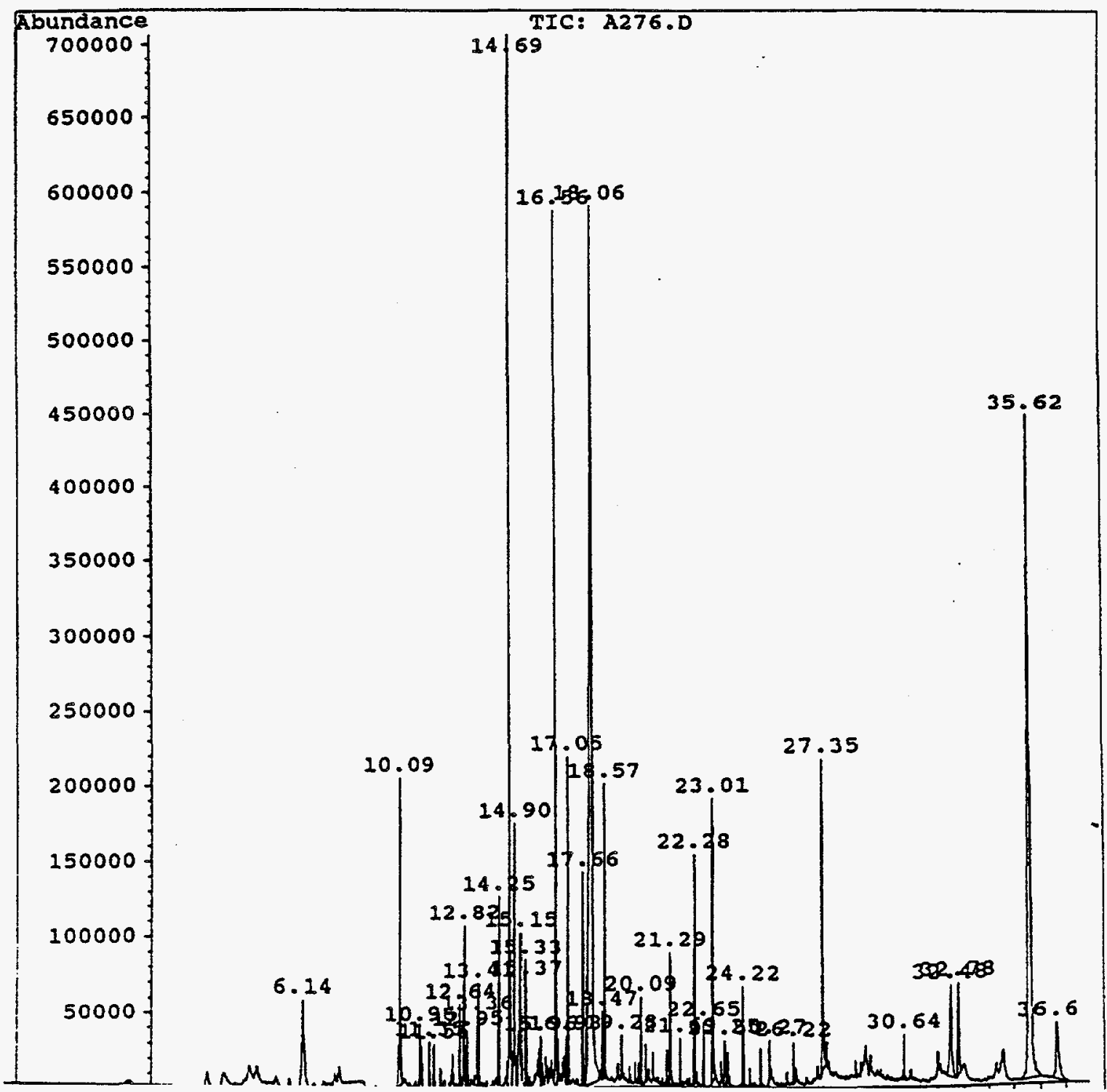



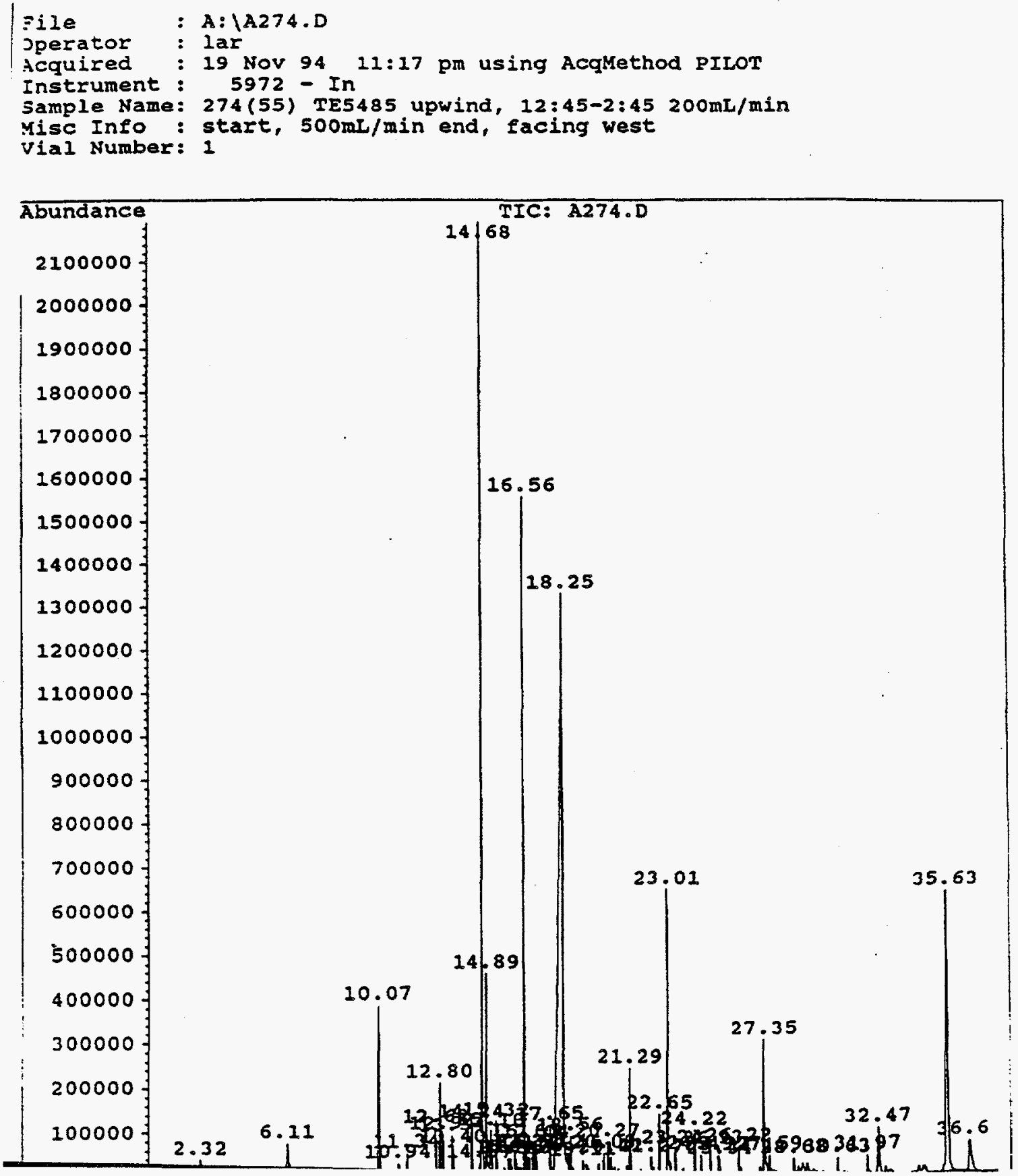

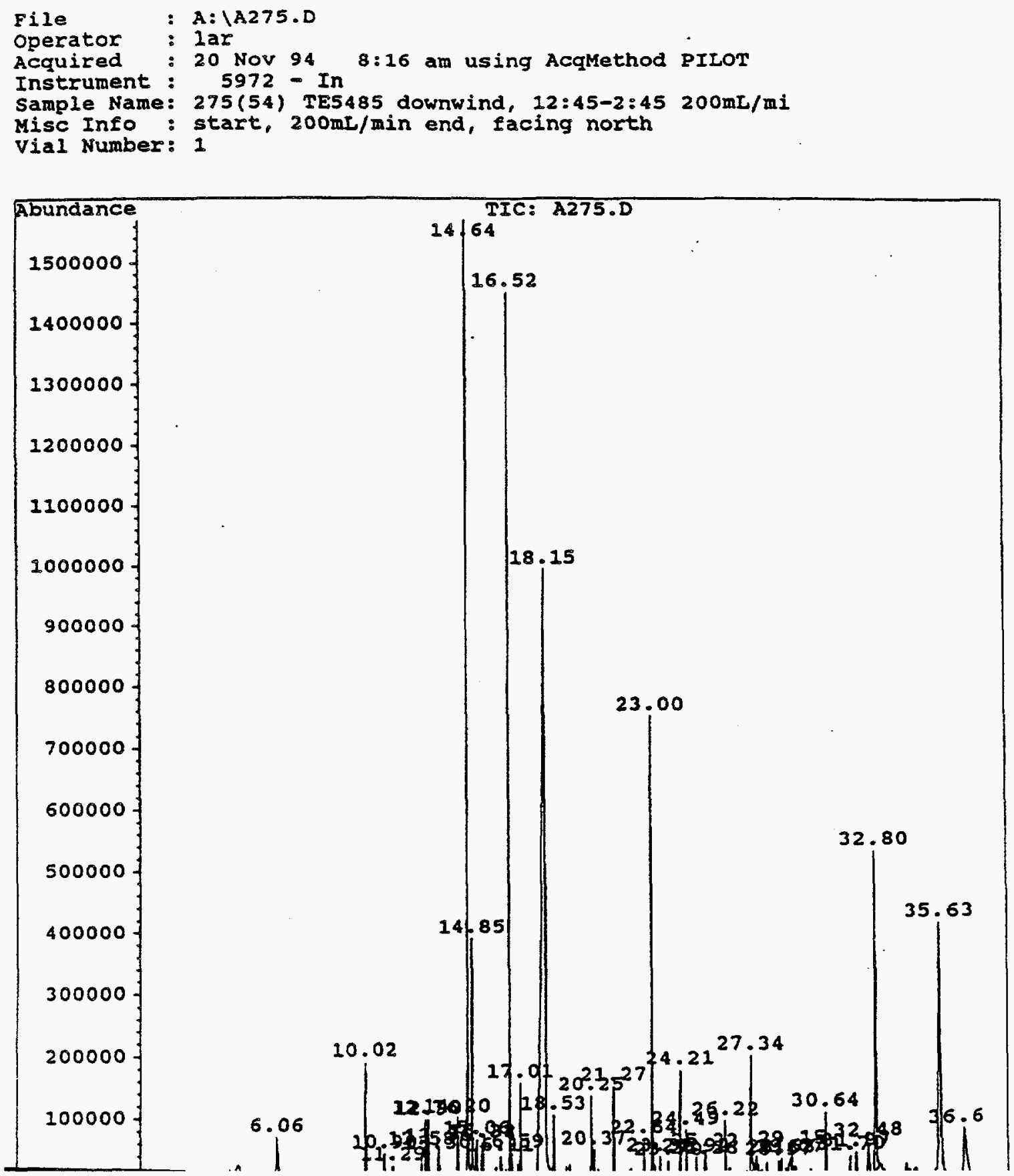


\begin{tabular}{|c|c|c|c|c|c|c|c|c|c|c|c|c|c|c|c|c|}
\hline \multicolumn{17}{|c|}{ Alr Sampling Data Sheet } \\
\hline & & & & & & & & & & & & & & \multicolumn{3}{|c|}{$-a^{2}$} \\
\hline \multirow{2}{*}{\multicolumn{3}{|c|}{$\begin{array}{l}\text { Date: il } / \mathrm{Ml} \text { ilt } \\
\text { Sample }\end{array}$}} & \multirow{2}{*}{\multicolumn{11}{|c|}{ 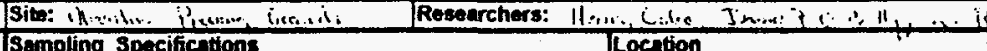 }} & 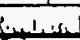 & L. & \\
\hline & & & & & & & & & & Locesti & & & & Ambien & it Conditai & \\
\hline Number & Building & Room & $\begin{array}{l}\text { Samp } \\
\text { Stent }\end{array}$ & $\begin{array}{l}\text { ing Time } \\
\text { End }\end{array}$ & $\begin{array}{l}\text { Flow } \\
\text { Initial }\end{array}$ & $\begin{array}{l}\text { Rale } \\
\text { Finat }\end{array}$ & $\begin{array}{l}\text { Pump } \\
\text { Setting }\end{array}$ & Pump 1D: & Manillold & Heigh & Distance *1 & Distance $* 2$ & Facing & $\begin{array}{c}\text { Temp- } \\
\text { ature }\end{array}$ & Pressure & Humidity \\
\hline $2 \%$ & $S_{r} \cdots \cdots:$ & : & $\therefore x$ & $\begin{array}{c}42 n \\
70 . .\end{array}$ & kions & $i \cdots=$ & $r^{2} \ldots$ & 5 & $5 A$ & 1:- & $\therefore \quad \therefore$ & $\begin{array}{r}\because \cdots \ldots \\
\quad \therefore \ldots \\
\end{array}$ & & $\because \ldots$ & $\ldots$ & $\therefore 1$ \\
\hline $2 m_{1}^{150}$ & $x_{x}: \cdots$ & $b_{0, m+3}$ & (3., & $\begin{array}{r}12 \cdot 24 \\
3,4 \\
\end{array}$ & $\geqslant \infty$ & P.s. & $\therefore \quad 1.5$ & .5 & 52 & $x 0^{-}$ & $\begin{array}{l}14 \cdot \text { Fnom } \\
4: \therefore \cdot u\end{array}$ & $\begin{array}{l}\because \cdots \\
\therefore \cdots \\
\end{array}$ & & $(x, 1)$ & - & it 1 \\
\hline $.2011^{1011}$ & $\because \ldots:$ : & $\because \therefore$ & $12 \ldots$ & $\therefore$ & $x \in \frac{m}{n-6}$ & ene $=\frac{1}{-\infty}$ & isi: & 4 & 411 & 16." & $\begin{array}{l}a \cdot 1.2 . \\
\cdots\end{array}$ & $\because \cdots \cdot$ & $(1, b+1)$ & 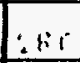 & $\because \ldots \ldots$ & \\
\hline $112^{(50)}$ & $\therefore \% \mu$ & 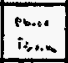 & $\ldots$ & .8 & in $\div$ & $\ldots$ & $p_{1}:$ & 4 & 43 & 11-" & • & .. & 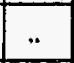 & L:: 1 & $\begin{array}{cc}\cdots & \ldots \\
\ldots & \cdots \\
\end{array}$ & \\
\hline $1 \% 0^{15 \% 1}$ & 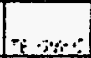 & conit & $\because 0$ & $\begin{array}{c}c+4 i \\
i \cdots\end{array}$ & $200 \%$ & $500 \frac{\mathrm{mb}}{n+\pi}$ & 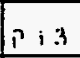 & $\stackrel{2}{2}$ & 6. 9 & $\because \because$ & 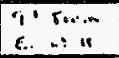 & $\begin{array}{lll} & \cdots & \\
a & & \\
\end{array}$ & {$[1, \ldots, 1$} & $x: 1$ & $\cdots$ & $\therefore$ \\
\hline $1 \cdots ;$ & $n-\sin =-$ & ins & 16" & $\begin{array}{c}i+4 \\
i m\end{array}$ & $x \frac{\mathrm{m}}{\mathrm{m}}$ & $200 \div$ & p $1 \ldots$ & 3 & 6.13 & e.: & 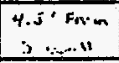 & $\begin{array}{l}4 \cdot r \times \ldots . \\
1.1 \quad \ldots .11\end{array}$ & Ar ath & iin & - & ..- \\
\hline $2 \%$ & Pt.,is.: & $\cdots$ & $12 \div 5$ & $\begin{array}{ll}2.4 \\
t_{1} \ldots\end{array}$ & $2^{\infty}, \frac{2 !}{\infty}$ & 2.00 & $i \quad \ldots$ & 2 & $i_{i}:$ & $160^{\circ}$ & $6^{\prime}$ Form & 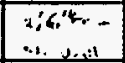 & (r.1.:-s. & $\pi$ & $=$ & $\because$ \\
\hline$j n$ & Fis $54 x$ & $\begin{array}{l}3+\ldots \\
x<\ldots\end{array}$ & $12=1$ & $\therefore:$ & $\operatorname{csi} \frac{1}{\vdots}$ & xeve $\frac{\mathrm{miz}}{\mathrm{min}}$ & $i \cdot 1.5$ & a & 14 & $\mathrm{BO}^{-}$ & - & .. & $(\ldots: \cdots:$ & $\eta^{\prime}$ & $\cdots$ & \\
\hline & & & & & & & & & & & & & & $=$ & & \\
\hline & & & & & & & & & & & & & & & & \\
\hline & & & & & & & & & & & & & & & & \\
\hline & & & & & & & & & & & & & & & & \\
\hline & & & & & & & & & & & & & & & & \\
\hline & & & & & & & & & & & & & & & & \\
\hline & & & & & & & & & & & & & & & & \\
\hline
\end{tabular}


